\title{
Chaetoceros ceratosporum Diatomae in Feed Formula To Increase Growth and Post Larvae Immunity of Tiger Shrimp (Penaeus monodon Fab.) to Vibrio harveyi infection
}

\author{
Arning Wilujeng Ekawati ${ }^{1 *}$, Happy Nursyam $^{2}$, Edi Widjayanto $^{3}$, Marsoedi $^{4}$ \\ ${ }^{1}$ Faculty of Fisheries and Marine Science, Brawijaya University, Indonesia \\ ${ }^{2,4}$ Faculty of Fisheries and Marine Science, Brawijaya University, Indonesia \\ ${ }^{3}$ Faculty of Medicine, Brawijaya University, Indonesia
}

\begin{abstract}
This experiment aims to determine the effect and the best dose of Chaetoceros ceratosporum diatomae utilization in feed formula for post larvae of tiger shrimp (Penaeus monodon Fab.) growth and immunity to Vibrio harveyi infection. This research applied Completely Randomized Design (CRD) with 4 treatments and 3 replications. The treatment use Chaetoceros ceratosporum diatomae in feed formula (iso protein $39.02 \%$ and iso energy $3.58 \mathrm{kcal} / \mathrm{g}$ diet) in different doses, i.e. treatment $A=0 \% ; B=3.04 \% ; C=6.08 \%$; $D=9.12 \%$. Observed parameters were Survival Rate, Growth Rate, Food Conversion Ratio (FCR) and Protein Efficiency Ratio (PER). Result showed that Chaetoceros ceratosporum diatomae utilization in feed formula affect the increase of growth and immunity of post larvae of tiger shrimp (Penaeus monodon Fab.) to Vibrio harveyi infection. The best dose in feed formula ranged from 5,75\% -5,95\%.
\end{abstract}

Key words: Chaetoceros ceratosporum, balance energy, feed conversion, protein efficiency, Vibrio harveyi, tiger shrimp

\section{INTRODUCTION}

In the decade of 1991, Indonesia experienced a peak production of shrimp; ranked second after Thailand, nevertheless post 1991, one of the problem is bacterial infection [1].

Several species of Vibrio bacteria that can be isolated from diseased shrimp are Vibrio parahaemolyticus, Vibrio harveyi, Vibrio alginolyticus and Vibrio vulvificalis, while Vibrio damsela, Vibrio anguillarum and Vibrio fluvialis rarely found. From the various types of Vibrio, Vibrio harveyi is often leading to $>100 \%$ death at larvae, post-larvae, juvenile, sub-adult and adult phase [2].

Various attempts to control the disease in shrimp farming has been carried out, i.e. health environment management, selection of healthy fry and feed processing as needed. Prevention and control of disease in shrimp should be done through an integrated approach to the factors that influence the onset of disease. These factors were associated with bacterial virulence and the shrimp's immunity.

The immune system is not separated by the availability of nutrients consumed by organisms, including shrimp. However, information on the association between the nutrients composition balance with the immune system of shrimp was not completed explored yet. An increase in

\footnotetext{
* Correspondence address Arning Wilujeng Ekawati

Email : ar_ning2000@yahoo.com

Address : Faculty of Fisheries and Marine Science, Brawijaya University, Jl. Veteran, Malang
}

immunity against disease not only by feeding with a balanced nutrient composition, but also by the provision of immunostimulant feed. Immunostimulant directly connected to immune system cells which make them more active. Immunostimulant addition (bacterin vibrio and yeast glucan) into shrimp (Penaeus monodon Fab.) enhanced the system activity of prophenoloxidase (pro-PO)[3]. Diatomae of Chaetoceros ceratosporum as natural feeding also improved shrimp's larvae immunity to Vibrio harveyi exposure $[4 ; 5]$ but whether it acts as an immunostimulant diatomaceous or not was still need to be investigated. Is the formula feed usage also promotes growth and post larvae immunity of shrimp against Vibrio harveyi infection or not.

This research aimed to determine the effect and best dose utilization of diatomaceous Chaetoceros ceratosporum in feed formula to increase growth and immunity of shrimp postlarvae (Penaeus monodon Fab.) towards the infection of Vibrio harveyi.

\section{MATERIALS AND METHODS Materials}

Materials used in this research are : Post larvae (PL) 20 Shrimp (Penaeus monodon Fabricus), compounds for feed formula, dried Chaetoceros ceratosporum, Vibrio harveyi bacteria and sea water with 30 ppt salinity as culture media. Chemical compound for natural feed, bacteria culture, feed compound proximate analysis and chemical compound to alnalyze immune responses. 


\section{Equipments}

Equipments for this research are : natural feed culture containers, shrimp container and maintenance equipments (aeration), bacteria culture equipments, feed compund proximate tools, feed manufacturing, water quality assessment. This research was conducted in two stages:

\section{Phase I:}

Chemical composition Evaluation of standard feed (rebon flour and tapioca flour) and dried Chaetoceros seratosporum comprise: water content with Oven, Protein by Kjedhal method, fat by soxhlet method, ashing by $600^{\circ} \mathrm{C}$.

Feed formulation for tiger shrimp (Penaeus monodon Fab.) by the addition of Chaetoceros seratosporum known chemical composition with various doses. Feed formula manufactured with $39.02 \%$ protein content and $3.58 \mathrm{k} \mathrm{kalg}^{-1}$ energy content according to previous research [6] as basic feed formula and using Chaetoceros ceratosporum as one of feed formula compound in different amount. Compositions of feed and feed formula were shown in Table 1 and 2. Reproximate analysis was conducted on feed and feed size was made suitable to shrimp size (crumble).

\section{Phase II:}

Feed formula assessments in laboratory scale were conducted to analyze the growth and the immunity of tiger shrimp (Penaeus monodon Fab.) to Vibrio harveyi infection with experimental Complete Randomized Design method.

\section{In Vivo Experiment Feed Assessment}

Used post Larvae (PL 20) in this experiment was from hatchery. Shrimps were nurtured in $45 \mathrm{x}$ $45 \times 45 \mathrm{~cm}^{3}$ aquarium filled with 30 ppt salinity sea water for $30 \mathrm{~cm}$ height. Each aquarium filled with 30 shrimps. Pada Table 2 explain the different dose of Chaetoceros seratosporum in each treatment, i.e. $A=0 \%$; $B=3.04 \% C=6.08$ $\% ; D=9.12 \%$. Each treatmenr were replicated three times. Feeding in $15 \%$ of body weight given in every day, at $08.00,16.00$, and 21.00 GMT/UTC+7, for $30 \%, 30 \%$ and $40 \%$ respectively. Hatchery took 30 days. Aquarium placement were shown in Fig. 1.

\begin{tabular}{|l|l|l|l|l|l|l|l|l|l|l|l|}
\hline D & A & C & B & A & B & C & D & B & C & A & D \\
2 & 3 & 1 & 3 & 1 & 2 & 3 & 3 & 1 & 2 & 2 & 1 \\
\hline
\end{tabular}

Tabel 1. Composition of experiment feed ingredients

\begin{tabular}{lccc}
\hline \multicolumn{1}{c}{ Analysis } & Rebon Flour & Plankton Flour & Tapioca Flour \\
\hline Dried content (\%)* & 86,34 & 85,38 & 89,4 \\
Protein (\%)* & 62,98 & 3,99 & - \\
Fat (\%)* & 1,59 & 0,29 & - \\
Ash content (\%)* & 17,05 & 66,84 & 0,59 \\
Rugged fiber (\%)* & 3,01 & 2,61 & - \\
\hline BETN $* *$ & 15,37 & 26,26 & 99,41 \\
Energy (kkal/gr)** & 327,69 & 123,65 & 397,64 \\
\hline
\end{tabular}

Explanation :

* : : Result Analysis of Laboratory Quality and Food Safety Assessment, Dept. of Agricultural Technology, Faculty of Agricultural Technology, Brawijaya University, Malang.

** : $\quad$ BETN $=100-$ Protein - Fat - Ash content - rugged fiber.

$* * * \quad: \quad$ Energy $=(4 \times$ Protein $)+(9 \times$ Fat $)+(4 \times$ BETN $)$.

Tabel 2. Experiment Feed Formula of tiger shrimp (Penaeus monodon Fab.)

\begin{tabular}{|c|c|c|c|c|}
\hline \multirow{2}{*}{ Ingredients } & \multicolumn{4}{|c|}{ Treatment Dose } \\
\hline & A (0\%) & B (3,04 \%) & $C(6,08 \%)$ & $\mathrm{D}(9,12 \%)$ \\
\hline Rebon flour & 61,96 & 61,96 & 61,96 & 61,96 \\
\hline Tapioca flour & 15,77 & 14,38 & 13,88 & 12,93 \\
\hline Flour of $C$. ceratosporum & - & 3,04 & 6,08 & 9,12 \\
\hline Fish Oil & 3,75 & 3,75 & 3,75 & 3,75 \\
\hline Corn oil & 6,50 & 6,50 & 6,50 & 6,50 \\
\hline Vitamin mix & 2,70 & 2,70 & 2,70 & 2,70 \\
\hline Mineral mix & 2,00 & 2,00 & 2,00 & 2,00 \\
\hline $\mathrm{CMC}$ & 7,32 & 5,22 & 3,13 & 1,02 \\
\hline Total & 100 & 100 & 100 & 100 \\
\hline
\end{tabular}


Observed parameter are growth for every 10 days, water quality of maintenance media (temperature, $\mathrm{pH}$, solved Oxygen and ammonia) and shrimp survival rates at the end of research. Furthermore, maintenance media filled with 20 shrimps infected with $10^{5}$ cellml $^{-1}$ Vibrio harveyi and 1 week survival rate was observed.

\section{Bacteria Culture of Vibrio harveyi}

Ose sterilized by heated above the Bunsen till incandescent. After ose ascertained being cold, Vibrio bacteria taken by touching the ose tip in stock. The surface of TCBSA media scratched with the quadrant streaking method to obtain separate colonies. Then it incubated in $30^{\circ} \mathrm{C}$ for 24 hours. Growing pure colonies identified to ascertain the species of bacteria. Having proven the species is Vibrio harveyi, enrichment cultures taken to produce in large quantities.

\section{Enrichment procedure}

Pure colonies were taken by sterile Ose, then putted into Erlenmeyer containing liquid medium of TSB +. Erlenmeyer re-closed with sterile cotton, and then putted in water bath shaker. It incubated then in $30^{\circ} \mathrm{C}$ shaking speed $100 \mathrm{rpm}$ for $2 \times 24$ hours. The culture results observed to make sure there is no contamination with gram staining and viewed by microscope. Then the bacterial culture density assessed with Mc Farland. Of the OD (Optical Dencity) measurement, diluted to get the desired bacterial density.

\section{Data Analysis}

\section{Shrimp Survival Rate}

Survived shrimp (indv.) compared to initial number of shrimp $\times 100 \%$.

Survival rate $=\frac{\sum \text { survived shrimp }(\text { indv. })}{\left.\sum \text { initial number of shrimp (indv. }\right)} \times 100 \%$

\section{Specific Growth Rate}

Specific growth rate calculations based on the average individual weight of shrimp during the study [7]:

$$
\mathrm{SGR}=\frac{\ln \overline{\mathrm{W}} \mathrm{t}-\ln \overline{\mathrm{W}} \mathrm{o}}{\mathrm{t}} x 100 \%
$$

Explanation:

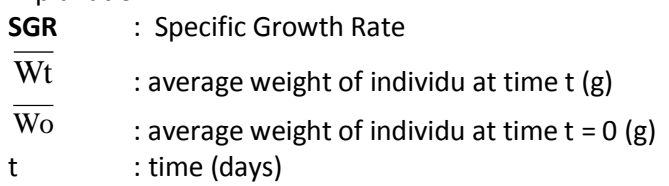

Feed Conversion Ratio (FCR)

$\mathrm{FCR}=\frac{\text { Given Feed }}{\text { weight gain }}$

Protein Efficiency Ratio (PER)

$\mathrm{PER}=\frac{\text { weight gain }}{\text { given protein }}$

Survival rate, Spesific Growth Rate, Feed Conversion Ratio (FCR), and Protein Efficiency Ratio (PER) anylzed using ANOVA. The response were tested with F Test [8].

\section{RESULT AND DISCUSSION}

Survival rate, Spesific Growth Rate, Feed Conversion Ratio (FCR), and Protein Efficiency Ratio (PER) of tiger shrimp (P. monodon Fab.) showed in Table 3 as follow. Water quality range during study showed in Table 4. Survival rate of post larvae of tiger shrimp (Penaeus monodon Fab.) were maintained for 30 days by experiments feeding that utilize plankton flour of C. ceratosporum were not significantly different, $78,90-84,43 \%$ (Table 3). Survival rate of shrimp survival is mainly determined by the physicalchemical properties of water and adequate feed. Physical-chemical properties of water in these experiments are in a good range for the survival and growth of shrimp in accordance with some expert advice (Table 5). Feed management is a key factor that affects the water quality [9] and economically produced in cultivation [10].

Feed management is an attempt to control and use feed in the cultivation in order to address these needs with the optimum feed residue and minimize environmental impact; improve the feed conversion ratio (FCR) as well as growth and maximum production [11]. Number of feeding in this research is $3 \% \mathrm{BB}^{-1}$ hari ${ }^{-1}$ with the frequency of 3 times hari ${ }^{-1}$. It corresponds with Wyban and Sweeney [12] that frequency of viable feeding for the hatchery is 2 - 4 times depends on shrimp's size. Although feeding manipulation had no effect on poduction, but it improve feed conversion value [13].

In this study, growth pattern of post-larval shrimp which weighted average of $0.021 \pm 0.001$ $\mathrm{g}$ is exponential. This reflects sufficient feed for the growth of post-larval shrimp. 
Tabel 3. Survival Rate, Growth Rate, Feed Conversion Ratio (FCR), and Protein Efficiency Ratio (PER) of Post Larval of Tiger shrimp (Penaeus monodon Fab.)

\begin{tabular}{|c|c|c|c|c|}
\hline \multirow{2}{*}{ Parameter } & \multicolumn{4}{|c|}{ Treatments } \\
\hline & A & B & $\mathbf{C}$ & D \\
\hline \multicolumn{5}{|l|}{ Pre-infection of $V$. harveyi: } \\
\hline Survival Rate (\%) & $80 \pm 3,3 a$ & $78,90 \pm 1,91 a$ & $84,43 \pm 1.96 a$ & $81,10 \pm 3,81 a$ \\
\hline Growth Rate (\%BW/day) & $6,51 \pm 0,33 a$ & $7,40 \pm 0,25 b$ & $8,23 \pm 0,25 c$ & $7,39 \pm 0,20 b$ \\
\hline FCR & $1,64 \pm 0,11 a$ & $1,37 \pm 0,07 b$ & $1,18 \pm 0,05 c$ & $1,37 \pm 0,05 b$ \\
\hline PER & $1,55 \pm 0,11 a$ & $1,84 \pm 0,09 b$ & $2,20 \pm 0,10 c$ & $1,89 \pm 0,07 b$ \\
\hline \multicolumn{5}{|c|}{ Post Infection of $V$. harveyi: } \\
\hline Survival Rate (\%) & $18,33 \pm 5,77 a$ & $56,67 \pm 5,77 b$ & $81,67 \pm 7,64 c$ & $53,33 \pm 5,77 b$ \\
\hline
\end{tabular}

Explanation: Same notation indicates indifference, whereas different notations indicate difference between treatments with confidence level $95 \%$

Table 4. Range of water media quality parameters of tiger shrimp (Penaeus monodon Fab.)

\begin{tabular}{lcccc}
\hline \multirow{2}{*}{ Treatments } & \multicolumn{4}{c}{ Water Quality Parameter } \\
\cline { 2 - 5 } & Temperature ( $\mathbf{~ C ) ~}$ & $\mathbf{p H}$ & $\mathbf{D O}\left(\mathbf{m g L}^{-1}\right)$ & $\left.\mathbf{N H}_{\mathbf{3}} \mathbf{( m g L}^{-1}\right)$ \\
\hline A $(0 \%)$ & $27-29$ & $7,84-8,44$ & $5,4-6,5$ & $0,018-0,038$ \\
B $(3,04 \%)$ & $27,5-29$ & $7,81-8,45$ & $5,5-5,7$ & $0,018-0,044$ \\
C (6,08\%) & $27,5-29$ & $7,77-8,25$ & $6-6,5$ & $0,012-0,026$ \\
D (9,12\%) & $27-29$ & $7,67-8,21$ & $5,6-6$ & $0,014-0,044$ \\
\hline
\end{tabular}

Table 5. Experiment Media Quality of Tiger Shrimp (Penaeus monodon Fab.)

\begin{tabular}{lcc}
\hline Water Quality Parameter & \multicolumn{2}{c}{ Water Quality Value } \\
\cline { 2 - 3 } & Study & References \\
\hline Suhu (o-C) & $27-29$ & $25-30[14] ; 25-31[15]$ \\
pH & $7,67-8,45$ & $7,5-9,0[16] ; 6,8-8,7[17]$ \\
DO $\left(\mathrm{mgL}^{-1}\right)$ & $5,4-6,5$ & $5-8[18]$ \\
$\mathrm{NH3}\left(\mathrm{mgL}^{-1}\right)$ & $0,012-0,44$ & $<0,1[19]$ \\
\hline
\end{tabular}

Survival rate on shrimp treatment B, C and D after infected by Vibrio harveyi showed different results compared to control without the use of $C$. ceratosporum (treatment A) (Table 5). Correlation between the numbers of $C$. ceratosporum in feed formula $(X)$ with a survival rate of shrimp postlarvae (Y1) after infected $V$. harveyi patterned a quadratic equation:

$$
Y 1=-1,128 X^{2}+12,97 X+23,85 ; R^{2}=0,90 .
$$

This equation showed that number of $C$. ceratosporum in feed formula that produced the highest survival rate $(61.12 \%)$ after infected $V$. harveyi was $5.75 \%$.

This indicates that the use of $C$. ceratosporum in feed formula increase immunity of shrimp. It is assumed that $C$. ceratosporum contain $\beta-(1-3)-$ glucans as an immunostimulant. Storseth et al. [20; 21] have proved the existence structures of $\beta$-D-(1$3)$-glucan on Chaetoceros mulleri. Furthermore, prove the structure of $\beta$-D-(1-3,1-6)-glucan on Chaetoceros debilis [22]. Results concluded that different diatom species has a structure of $\beta$-D-(13)-glucan and different molecular weight. This study also explained the use of $C$. mulleri can improve the survival and growth of Cod fish larvae. In line with the role of $C$. ceratosporum to increase immunity, then followed by an increase in specific growth rate, feed conversion ratio and protein efficiency ratios.

Growth is closely related to feed, because feed provide nutrients and energy needed for growth. Correlation between the number of $C$. ceratosporum in feed $(\mathrm{X})$, growth rate (Y2), feed conversion (Y3) and efficiency ratio (Y4) post-larval shrimp with patterned quadratic equation:

$$
\begin{aligned}
& Y 2=-0,046 X^{2}+0,538 X+6,432 ; R^{2}=0,81 \\
& Y 3=0,012 X^{2}-0,147 X+1,653 ; R^{2}=0,79 \\
& Y 4=-0,016 X^{2}-0,194 X+1,515 ; R^{2}=0,80
\end{aligned}
$$

Based on these equations derived that the best rate of growth, feed conversion and protein efficiency ratio $\left(7,99 \% \mathrm{BW}^{-1} \mathrm{day}^{-1}, 1,22\right.$ and 2,02 respectively), obtained the use of $C$. ceratosporum in feed formula are $5.78 \%, 5.86 \%$ and $5.95 \%$ respectively. Growth rate is influenced by the balance of energy/protein in the feed. In this study, a proportion of energy/protein feed is $10,89 \mathrm{kka} \mathrm{g}^{-1}$ protein. Balance energy/protein in the optimal feed for Litopenaeus vannamei is $11,9 \mathrm{kkal} \mathrm{g}^{-1}$ protein [23]. If the balance of feed energy/protein is 3.37

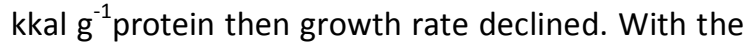
increase of growth rate will be followed by an 
increase in feed conversion and the efficiency of protein utilization.

The feed conversion ratio is affected by several factors but the most important is the quality and quantity of feed, species, size and quality of water [24]. Low feed conversion value indicates better utilization and well absorbed by the body to promote growth. The improvement of feed conversion values is caused by high nutrients that is not used optimally by the body or in other words wasted in the form of feces.

Feed Conversion in this study is 1,22 . This value is better than the results of Venero [25], i.e. 1,8 with balance energy/protein in feed $9 \mathrm{kkalg}^{-1}$ protein. It showed the roles of $C$. ceratosporum in increasing immunity, means energy for surviving was more efficient and the rest energy used for growth process. Furthermore, by the increase in growth rate, then feed utilization will be more efficient. Similarly, protein efficiency ratio will also be more efficient because the protein will be used for growing. These results are supported by the results of tests on the immune response of shrimp.

\section{CONCLUSION}

Based on the results, this study concluded that the use of diatomaceous Chaetoceros ceratosporum in feed formula increase growth and immunity of post-larvae shrimp (Penaeus monodon Fab.). The best dose is $5.75 \%-5.95 \%$ in the feed formula.

\section{REFERENCES}

[1] Winarno, B. 1995. Shrimp aquaculture in Indonesia. In C. L. Browdy and J. S Hopkins (Eds.) Swimming through Troubled Water. Proceeding on Shrimp Farming, Aquaculture '95. World Aquaculture Society, Baton Rouge. Lousiana. USA. 24-28.

[2] Ruangpan, L. 1998. Luminous Bacteria Assosiated with Shrimp Mortality. In T. W. Flegel (Ed) Advances in Shrimp Biotechnology, National Centre for Genetic Engineering and Biotechnology, Bangkok. 205-2011.

[3] Devaraja, T.N., S.K. Otta, G. Shubha, I. Karunasagar, P. Tauro, I. Karunasagar. 1998. Immunostimulation of shrmp through oral administration of Vibrio bacterin and Yeast Glucan. In T.W. Flegel (Ed) Advances in Shrimp Biotechnology, National Centre for Genetic Engineering and Biotechnology, Bangkok. 167-170.

[4] Kartikaningsih, H., A.W. Ekawati, Sukoso, Haryanti and Zafran. 1999. The use of Dried Phytoplankton Chaetoceros ceratosporum to Inhibit Development of Vibrio harveyi. ARMP. 1998/1999.
[5] Kartikaningsih, H, A.W. Ekawati, Haryanti and Rosa. 2000. The use of Dried Phytoplankton Chaetoceros ceratosporum to Inhibit the Development of Vibrio harveyi. ARMP. 1999/2000.

[6] Ekawati, A. W. 1990. Effect of feed protein content on the growth of post-larval of Tiger Shrimp (Penaeus monodon Fab.). Master Thesis, FPS, IPB, Bogor. 71 pp.

[7] De Silva, S.S. and T.A. Anderson. Fish Nutrition in Aquaculture. Chapman \& Hall, 2-6 Boundary Ror, Lndon SE1 8HN. UK. 319 pp.

[8] Chin, T. S. and J. C. Chen. 1987. Acute toxicity of ammonia to larvae of the tiger prawn, Penaeus monodon Fab. Aquaculture, 66:247253.

[9] Boyd, C.E. and C.S. Tucker. 1998. Pond Aquaculture Water Quality Management. Kluwer Academics Publisher, Boston, Massachutets, USA.

[10] Jolly, C.M. and H.A. Clonts. 1993. Economics of Aquaculture. Food Product Press, Binghamton, New York.

[11] Ali, S.A. 2002. Feed management in shrimp and finfish aquaculture. Central Institute of Brackishwater Aquaculture, CHENNAI-600028. 75-81.

[12] Wyban, J.A. and J.N. Sweeney. 1991. Intensive shrimp production technology. The Oceanic Institute, Honolulu, Hawaii, USA.

[13] Snedecor, G.W. and W.G. Cochran. 1980. Statistical methods ( $7^{\text {th }} \mathrm{Ed}$.) The lowa State Univ. Press. lowa. 507 pp.

[14] Barono, D. Adiwidjaja, M. Mariyan and B.S. Ranoemihardjo. 1986. Shrimp farming. INFIS Man. Ser. 31, 85 pp.

[15] Soundarapandian, P., K. Sankthivel and G.K. Dinakaran. 2009. Culture of Penaeus monodon (Fabricius) by using cyclop-eeze feed. Current Research Journal of Biological Sciences 1(3):113-117.

[16] Kungvankij, P., T. E. Chua, J. Pudadera, Jr. G. Corre, B. Alava, I. B. Tiro, Jr. I. O. Potestas, G.A. Taleon and J.N. Paw. 1986. Shrimp Culture: pond design, operation and management. NACA Training Manual Series. No. 2, 68 p.

[17] Ramanathan, N., P. Padmavathy, T. Francis, S. Athithian and N. Selvaranjitham. 2005. Manual on polyculture of tiger shrimp and carps in freshwater, Tamil Nadu Veterinary and Animal Sciences University, Fisheries Cooledge and Reseach Institute. Thothukudi, 1-161.

[18] Wardoyo, S.T.H. and D. Djokosetjanto. 1988. Water quality management in shrimp ponds. Seminar of The success and spur business 
development of shrimp aquaculture. $16-17$ September 1988. Faculty of Fisheries, IPB, Bogor. $24 \mathrm{pp}$.

[19] Zelaya, O. 2005. An Evaluation of Nursery Techniques and Feed Management During Culture of Marine Shrimp Litopenaeus vannamei. Doctoral Dissertation. Auburn University, Auburn, Alabama, USA.

[20] Storseth, T.R., K. Hansen, J. Skejermo and J. Krane. 2004. Charakterisation of a $\beta-D-(1-3)-$ glucan from marine diatom Chaetoceros mulleri by high-resolution magic-angle spinning NMR spectroscopy on whole algal cells. Carbohydrat Research, 339:421-424.

[21] Storseth, T.R., K. Hansen, K.I. Reitan and J. Skejermo. 2005. Sructural characterization of $\beta$-D-(1-3)-glucans from different growth phases of the marine diatoms Chaetoceros mulleri and Thalasiosira weissflogii. Carbohydrat Research, 240:1159-1164.

[22] Storseth, T.R., S. Kirkvold, J. Skjermo and K.I. Reitan. 2006. A branced $\beta-D-(1-3,1-6)$-glucan from the marine diatom Chaetoceros debilis (Bacillariophyceae) characterized by NMR. Carbohydrat Research, 341:2108-2114.

[23] Cousin, M., G. Cuzon, E. Blanchet, E.F. Ruelle, AQUQACOP. 1993. Protein requirements following an optimum dietary energy to protein ratio for $P$. vanname Juveniles. In: S. J. Kaushik, P. Luquet (Eds.), Fish Nutrition in Practice, INRA, Paris, France, 599-606.

[24] NRC. 1993. Nutrient Requirements of Fish. Nutrient Requirements of Domatic. Washington DC. 144 pp.

[25] Venero, J. 2006. Optimization of Dietary Nutrient Inputs for Pacific White Shrimp Litopenaeus vannamei. Doctoral Dissertation. Auburn University, Auburn, Alabama, USA. $145 p p$. 